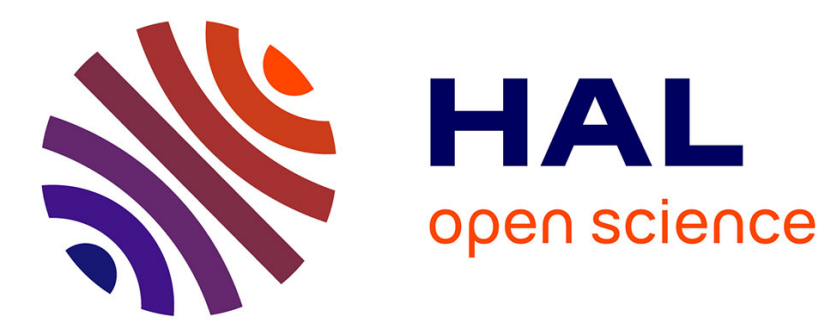

\title{
Painful Places: ritual encounters with one's homelands
}

Michael Houseman

\section{To cite this version:}

Michael Houseman. Painful Places: ritual encounters with one's homelands. Journal of the Royal Anthropological Institute, 1998, 4 (3), pp.447-467. halshs-00119425

\section{HAL Id: halshs-00119425 https://shs.hal.science/halshs-00119425}

Submitted on 9 Dec 2006

HAL is a multi-disciplinary open access archive for the deposit and dissemination of scientific research documents, whether they are published or not. The documents may come from teaching and research institutions in France or abroad, or from public or private research centers.
L'archive ouverte pluridisciplinaire HAL, est destinée au dépôt et à la diffusion de documents scientifiques de niveau recherche, publiés ou non, émanant des établissements d'enseignement et de recherche français ou étrangers, des laboratoires publics ou privés. 


\title{
Painful places: ritual encounters with one's homelands"
}

\author{
Michael Houseman (EPHE, Paris) \\ (Journal of the Royal Anthropological Institute (N.S.) 4 : 447-467,1998)
}

\begin{abstract}
This article explores the role of pain in a number of ritual performances entailing the construction of characteristic connections between people and their homelands: the English custom of Perambulation or Beating of the Bounds, the gisaro ceremony of the Kaluli of Papua New Guinea and the initiation rites of the Australian Aranda. By focusing on the distinctive relational forms acted out in these performances, the author shows how the ritual infliction of suffering at once imbues pre-existing links with land with the immediacy of new, incontestable bodily experiences, and embeds these experiences within a wider network of ties, namely, those presupposed by the pain-inducing relationship enacted in the rituals themselves. Through such recontexualisations, the participants' attachments to the places they live on are renewed and transformed.
\end{abstract}

\section{Ritual, place and pain}

The analyses that follow lay particular emphasis on the relational logics ritual brings into play. Specifically, ritual performances are viewed as the enactment of special types of relationship (Houseman 1993; Houseman and Severi 1994). Part of what makes ritual relationships so special is that they bring together in a single sequence of actions a plurality of pre-existing ties, generally drawn from a variety of domains: subsistence, the life cycle, kinship, other ceremonial events, and so forth. When for instance a Iatmul man performs naven for his (classificatory) sister's child - dressed up as a laughingly dishevelled widow, he goes looking for his young "husband", proclaiming his desire to catch the latter in the net he carries; after having rubbed his buttocks on his sister's child's leg, he presents him/her with food in return for shell valuables --, gender antagonism, maternal nurturance, sexual intimacy, affinal enmity, fishing and totemic ties are inextricably combined (Bateson 1958; Stanek 1983; Houseman and Severi 1994). By bringing disparate relations together in this way, ritual actions integrate them into higher-order relational networks, such that they may be appreciated as the interconnected aspects of ordered wholes.

Another feature of ritual relationships which makes them so special is that their enactment is systematically constrained by interactive dynamics entailing the condensation of nominally incompatible modes of relationship. Thus in the naven ceremony, parent-child ties and those between sexual partners, normally antithetical, are dramatically fused, as are crosssex and same-sex relations, and more generally, the processes of symmetrical and complementary differentiation. Rituals abound in such seemingly anomalous episodes in which, for example, affirmations of identity are at the same time testimonies of difference, displays of authority are also demonstrations of subordination, the presence of persons or other beings is at once corroborated and denied, secrets are simultaneously dissimulated and revealed, and so forth. To the degree that ritual performances incorporate such exceptional situations, they become readily recognisable as distinct from everyday interaction: they can not be fully accounted for in terms of ordinary intentionalities and patterns of relationship.

\footnotetext{
* Acknowledgements. In memory of my father John Houseman / Jacques Haussmann. An initial version of this paper was presented at the "Social organisation and systems of representation" (Equipe 4) seminar of the Laboratoire d'ethnologie et de sociologie comparative, Université Paris X - Nanterre. I would like to thank P. Menget and the participants for their helpful suggestions. I would also like to thank M. Anspach, P. Boyer, N. Journet, C. Malamoud, M. Moisseeff, C. Severi, A.-C. Taylor, E. Viveiros de Castro, H. Whitehouse as well as the Journal's readers who were kind enough to comment upon (several) earlier drafts.
} 
The distinctive 'work' of ritual which derives from the acting out of these special types of relationship is best envisaged neither as the production of particular messages to be deciphered, nor as a means for buttressing existing social structures, but rather as the generation of peculiar, highly integrative contexts for discourse and action, in the light of which participants' prior and subsequent experiences and knowledge are conventionally redefined. As such a process of recontexualisation, ritual has two complementary entailments. On the one hand, because it involves the condensation of nominally contrary modes of relationship drawing upon a wide variety of pre-existing ties, it gives rise to complex, highly evocative behaviours: distinctive actions, utterances and artefacts. In other words, it entails the definition of a specific symbolism. On the other hand, to the extent that it consists, as I have suggested, in the acting out of relationships, it presupposes the designation of particular agents. The latter may be persons such as parents, children, classificatory uncles, clan or village community members, alliance partners, enemies and so forth. However, they may also be non-human entities such as spirits, gods, totemic ancestors, animals, objects, words or locations which, for the participants, take on the attributes of agency. The ritually designated non-human entities which I will be particularly concerned with here are places: certain observable features of the natural or man-made environment such as outcrops of rock, rivers, hills or fields. These places are well-known to the ritual participants, who live in proximity to them, work them, play on them, look after them, etc. They are, in a word, their homelands. The ritual performances to be analysed here are therefore not foundation rites (e.g. Detienne 1990), but ceremonial occasions in which peoples' prior connections with place are reframed and thereby transformed. ${ }^{1}$

It is worth emphasising that the consequences of the ritual process as outlined above, that is, the particular symbolism and the designated agents it gives rise to, as well as the relational network it implies, does not require that the participants have a definite conceptualisation of the ceremonial actions they perform. Indeed, as has often been pointed out, the 'deeper meaning' of such actions may remain unclear for them. Rather, it is the performances themselves that serve as the touchstone reference for these emergent effects. It is important, however, that the participants be affectively committed to these enactments, that the ritual relationships these enactments instantiate, with particular places for example, are not merely abstract connections posited between hypothetical terms, but experiential truths sustained by intentionally and emotionally laden events. On a very basic level, the participants' involvement in this way is ensured by the fact that ritual is in essence a mode of bodily activity. However, more expedient measures may also be brought into play. A particularly obvious one which I will focus on here is the imposition of pain.

\footnotetext{
${ }^{1}$ This paper is thus primarily concerned neither with peoples' cultural conceptions of space per se, nor with the spatial aspects of ritual activity, both of which have received considerable attention elsewhere. On the one hand, detailed descriptions of local understandings of the lived-in environment -- houses, villages, countrysides, cosmologies, etc. -- are too numerous to mention. My aim is not to add to such accounts but instead to explore how certain rituals may contribute to making these cultural topographies plausible. On the other hand, the spatial dimension of ritual events has been emphasised by a number of authors. For those adopting a performative approach to ritual (e.g. Kapferer 1991; Schieffelin 1985; Schechner and Appel 1990) for example, questions regarding the scale, the scenic design and the progressive transformation of the ceremonial setting are major concerns. Others, in keeping with the view that ritual privileges physical action (rather than words), and hence presupposes phasal movement, directionality, and positioning, have suggested that most if not all rituals may be seen as rites of passage (Parkin 1992) or 'sacred journeys' (Werbner 1989) of one sort or another. Finally, the idea of ritual emplacement has been extensively developed by Smith (1987) who, among other things, has stressed the attention-directing quality of both place and ritual, notably in the case of built ritual environments such as temples. In the following pages however, place, and more generally space, is approached not as an organising property of the ritual enactments examined but as one of the terms of the relationship which these enactments may be held to bring about.
} 
Familiarity with place - indeed spatial orientation in general -- is closely linked with experience and bodily feelings. As Gussow has observed, 'The catalyst that converts any physical location -- any environment if you will -- into a place, is the process of experiencing deeply. A place is a piece of the whole environment that has been claimed by feelings' (1971: 27 quoted in Smith 1987: 30 ; cf. also Tuan 1977 ; Hirsch and O'Hanlon 1995). Along complementary lines, in many cultural traditions, especially those pertaining to the treatment of illness, the body and the surrounding environment are presented as two mutually responsive 'worlds' (e.g. Héritier 1984; Severi 1987). In this light, it should come as no surprise that ritual performances which afford community members with transformative encounters with their homelands are often centred upon bodily sensations, and specifically, upon that particularly unnegotiable sensation which is pain.

It is also significant, however, that the suffering undergone in these performances is inflicted, for as such, it is indissociable from the interactive conditions in which it occurs. Thus, while forging an intimate, bodily connection between the persons and places in question, inflicted pain also simultaneously acts to embed this connection within a larger network of interpersonal ties. As a result, linkages between persons and features of the environment, between such features, and between persons themselves, are integrated into a unitary configuration -- a network of relationships -- at once grounded in the indisputable immediacy of personal experience (of pain) and structured by the relational dynamics these conventional performances (entailing the infliction of pain) enact. Moreover, to the extent that the pain involved is perceived as purposefully imposed, these effects concern not just those who suffer but all of the ritual's participants, as well as those who anticipate the rituals' occurrence or who hear about it afterwards. Because their own personal experiences have made them aware not only of what it is to feel pain, but also of what it is to inflict it and/or to have it inflicted upon one, they find themselves caught up in the pain-inducing performances they acknowledge, and hence, in the relational networks these performances imply.

\section{Beatings at the Bounds}

The English custom of 'beating the bounds' during an Ascension Day procession known as a perambulation or Rogationtide walk, undertaken in order to 'deprecate the vengeance of God, beg a blessing on the fruits of the earth, and preserve the rights and properties of the parish' (Brand 1870: v.1, 114), derives from the Roman Catholic observation of Rogation days (from Latin rogare, 'to ask', 'to beseech'). These were periods of intercession or prayer characterised by the chanting of litanies of the saints in procession. Initiated in 470 by Saint Mamertus, bishop of Vienne, such processions became generalised to all the churches of Gaul in the 6th century (Leclercq 1932: 2459). By the 8th century, Rogation processioning had spread to Britain 'where it soon merged with an already longestablished custom of fixing territorial boundaries by walking them annually, preceded by a cross, banner or holy relic, on 'Cross' or 'Ganging' (Old English: 'going', 'walking') Days' (Kightly 1986: 48). With the Reformation, processions associated with transubstantiation (Corpus Christi), with the Blessed Virgin or with the saints were eliminated from the Anglican liturgy. However, perambulations of parish and manor bounds, enjoined by the 1559 Injunctions of Queen Elizabeth I, continued to be widely observed until their decline with the enclosure of common fields in the 18th and early 19th centuries (Bushaway 1982). This practice is currently observed on or around Ascension day in a number of regions (Kightly 1986: Annex 1). 
In a perambulation, a crowd of adults, led by a community representative (clergyman or steward) and accompanied by a group of children (usually boys), walked in procession around the parish or manor bounds, halting at vital landmarks for the epistle to be read and/or to reiterate the boundary lines. At each of these stops, the accompanying children were subjected to various types of hazing:

'In order that they may not forget the lines and marks of separation they "take pains" at almost every turning. For instance, if the boundary be a stream, one of the boys is tossed into it; if a broad ditch, they boys are offered money to jump over it, in which they, of course, fail, and pitch into the mud, where they stick as firmly as if they had been rooted there for the season; if a hedge, a sapling is cut out of it and used in afflicting that part of their bodies upon which they rest in the posture between standing and lying; if a wall, they are to have a race on top of it, when, in trying to pass each other, they fall over on each side, some descending, perhaps, into the still stygian waters of a ditch, and others thrusting the 'human face divine' into a bed of nettles; if the boundary be a sunny bank, they sit down upon it and get a treat of beer and bread and cheese, and, perhaps, a glass of spirits' (Udal 1922: 35-36).

Such rough treatment served to 'remember' the children (Kightly 1986: 49), 'to impress on their youthful memories both the situation and the substance of the parish [or manor] boundary at that point' (Hackwood 1974: 24). However, what exactly do such 'rememberings' involve? As a number of accounts make clear, the youths are often already aware of the parish's or manor's limits. Indeed, perambulations generally took place every year such that these boundaries were more or less known to all. Thus, what seems to be at stake here is not so much an accurate notion of the territory's boundaries, as a certain personal experience of these boundaries. It is the latter, rather than the former, that acts as the touchstone of truthful testimony. Consider the following case:

'When the Wolverhampon boundaries were being beaten in 1775 , an old man named Walter Gough was examined respecting the boundary of the parish on the east side [...]. This witness said he remembered because when he was fifteen years old he was thrown by the Parish Clerk into a heap of nettles that grew near, in the Rogation Week perambulation [...]. [The other party] not having a witness whose memory went back so far, had to yield its claim' (Hackwood 1974: 24-25).

The crucial factor in the resolution of this conflict was not the old man's topographical knowledge, most probably shared by others, but the fact that he had been personally affected by the disputed boundary area during a peramulation.

The underlying idea here is that the familiarity of place that counts, derives from a particular ritual relationship with the places in question, entailing a somewhat equivocal bodily experience of them. Thus, the 'impressing of memory' as the local idiom would have it, consists in bringing about a certain mindfulness of territory not indirectly, by means of an abstract conceptualisation of the perambulated land, but directly, by means of a certain intimate physical encounter with it. This intent is clearly expressed, for example, in a recurrent feature of processioning in which the victim's head is placed in direct contact with the terrain being perambulated: 'at each halting point, one of the visitants is bumped smartly against the boundary-stone, or placed head downwards against it' (Brand 1848: 114; also Hazlitt 1905: 523). ${ }^{2}$

\footnotetext{
${ }^{2}$ Such events seem to have often attracted the attention of photographers: Drake-Cornell (1938, figure 34) provides a photograph of 'standing a choir-boy of St. Clement Danes [London] on his head in the temple gardens', and Kightly (1986: 49) a 1977 picture in which 'a child is upended to 'remember' her of the parish boundary'. In Christian (1969, plate 59), a photograph of one of the two 'bumpings' included in the (biennial)
} 
Now, the actualisation of the ritual relationship between the children of the parish (or manor) and the latter's land, in these and other ordeals, simultaneously corroborates two further ties. On the one hand the link between the processioning community and its corresponding territory is formally confirmed. This is attested by the community representative's supervisory position during the hazing episodes, the participation of the processioning parishioners as observers, and by the subsequent role played by the youths' testimonies in cases of boundary disputes. At the same time, by interacting with the boundary markers, perambulation victims become incorporated into the collective identity whose territory these markers circumscribe. This is why not only children, but other recently arrived individuals are also subjected to hazing (Knightly 1986: 48, see also Brand 1870: 114). ${ }^{3}$ Moreover, in most accounts, the persons mistreated during processionings were entitled to refreshments and/or payment offered by community representatives (e.g. Drake-Carnell 1938: 78; Hackwood 1974: 24). These gatherings, during which the poor were fed and conflicts among parishioners resolved (Powers-Beck 1995), were occasions in which at once the parish's or manor's corporate identity as a land-holding body was made manifest and the victims' integration within the celebrating community was ratified. ${ }^{4}$

The youths' and others' hazing experiences enact, then, a necessary connection between two ties: on the one hand, that linking the celebrating community to the perambulated territory, and on the other hand, that linking the youths and others who undergo these ordeals to this celebrating community. Processioning integrates these two ties into a single relational network in which the local community, it's children (and other recently arrived members) and its land are bound together. The 'work' of perambulation ritual thus consists in a distinctive recontexualisation or framing of the youths prior (and subsequent) experience and knowledge of the land they live on. In the absence of processioning, their connections with their home territories remain particularistic and contingent, a mere reflection of their respective life trajectories. However, through this ritual, these connections acquire, for all concerned -- themselves, the parish or manor representatives and onlookers alike -- a generally acknowledged certainty and take on added significance. They are rendered inseparable from the further links which this ceremonial performance implies: membership in a particular community of persons and this community's ongoing attachment to a specific stretch of land.

The experiences through which the youths acquire this ritual relationship with the territory they perambulate is painful, or at the very least, physically constraining and markedly unpleasant. ${ }^{5}$ At the same time, these experiences are organised in such a way that

perambulation of the Manor and Liberty of the Savoy in London, shows a choir boy being 'bumped' at Cleopatra's Needle by being held upside down and his head struck against the stone.

${ }^{3}$ For example, 'a curious part of the ceremony [at the parish of Saint Mary, Leicester] was the seizure of any newly-appointed official to the parish at a certain bank of earth where a hole has been dug. The new-comer was forced head-foremost into the hole and his 'latter end' saluted with a shovel' (Hull 1928: 79-80). Similarly, in the non-ecclesiastical perambulation of Newbiggen-by-the-sea (Northumberland), 'new freeholders have to submit to a rough initiation ceremony. They are taken to the Dunting Stone on Newbiggin Moor, lifted by the feet and shoulders by senior freeholders and 'dunted' or bumped three times against the stone' (Christian 1966: 63, also Plate 61; cf. also Whitlock 1976: 55; Porter 1069: 116).

${ }^{4}$ Indeed, as the perambulation previously quoted at length suggests, such offerings may also be seen as part of the 'remembering' process itself. In some cases vexation and reward may be combined into a single action, as in the practice of throwing hot pennies for the boys to scramble for, attested for in Oxford perambulations from 1876 (Kilvert 1876, quoted in Christian 1966: 61) to 1994 (Scott 1995).

${ }^{5}$ Within the context of increased urbanisation, one of the ways of placing processioning children in close, unpleasant contact with the perambulated territory, is to require that they follow the boundary lines exactly, regardless of where they may lead. Under these conditions, as Christian (1966: 66) suggests, 'beating the bounds can still be an uncomfortable business for those who do it conscientiously'. Thus Burne writes in 1883 (1974: 
the infliction of pain takes place in the absence of the feelings and dispositions which ordinarily accompany the imposition of suffering: agency, anger, a desire to harm, etc. As a number of accounts show, the youths are typically not so much coerced as they are invited to take the initiative themselves, always with disastrous results. To the extent that some paininflicting other may be said to exist, it is less the supervising adult(s) than it is the very physical environment these youths perambulate. Pricked by bushes, drenched by streams, 'bumped' by stones and trees, thrown from walls, muddied in ditches, inconvenienced by buildings or rivers, etc., the youths are abused by the terrain itself. It is the passive, presumably desireless and unfeeling territory that nevertheless inflicts pain upon the youths. In order to fully appreciate the implications of this, it is necessary to briefly examine a recent evolution in the practice of perambulation.

The Victorian era seems to have brought about a transformation in the performance of processioning. Whereas previously, the characteristic feature of this custom was the hazing of parish or manor children, processioning became increasingly organised around the striking of boundary markers with long sticks, operation most often undertaken by the children themselves. This transition, whose description requires another article, was, of course a gradual one, allowing for a variety of mixed forms and local variations. However, the overall direction of change is clear: the youths, formerly victims, become the aggressors. At the Oxford perambulation of Saint Michael's, for example 'at each of the marks the vicar cries "Mark!" and the choirboys shout "Mark!, Mark!, Mark!" as they beat it, until told to stop' (Shuel 1985: 106); and at each of the thirty one Crown Boundary Marks along the triennial Tower of London Perambulation, it is the duty of the Chief Yeoman Warder 'to cry out "Cursed is he who moves his neighbours land mark. Whack it boys, Whack it!" Whereupon the choirboys set about it with manic enthusiasm' (Shuel 1985: 106).

The last 200 years have thus witnessed an inversion in the practice of processioning. In the former version, parish (or manor) children are abused by the lands they are pitted against in hazing episodes. An identification between the perambulated territory and the supervising community representatives is involved. In the latter version, the children are enjoined to attack the territory itself. Here, there is an identification between the youths and the community representatives who direct them. In both cases, the violent ritual relationship enacted between the young people and the their homelands establishes a necessary link between the tie joining the celebrating community to the perambulated territory on the one hand, and the tie joining the youths (and other recently arrived individuals) to the celebrating community on the other. The prime expression of this is of course the youths' subsequent ability to provide indisputable testimony regarding boundary lines in inter-community disputes. Through processioning, these individuals' familiarity with their homelands becomes imbued with a measure of culturally recognised authority. The singular character of these rememberings, that is, the seemingly unquestionable authority which perambulation bestows, derives, of course, from the highly specific nature of the ritual experience they undergo. Let us consider it a bit more closely.

The ease with which the transition has been made from one version of processioning to the other, as well as the possible coexistence of their respective, contrary patterns of

344) of 'The old-fashion Rogation-day procession of parish dignitaries [with a] company of little boys who were made to clamber over house-roofs and put into odd holes and corners'. Hackwood (1974: 24) cites a Staffordshire case in which 'a man was always made to climb over the roofs so that the boundary line might be accurately struck'. Similarly, according to Brockie, '[A]s the boundary line between [Sunderland] and Bishopwearmouth parish[es] passes in one place at least through the middle of a house, some amusement is naturally caused by the perambulators making their way from the street in at a certain upstairs window and out again by the back' (1974 [1886]: 102). For further example, cf. Christian (1966: 60) ; Kightly (1986: 48); Udal 1922: 37; Drake-Carnell 1938: 78). 
interaction in the same ritual performances, are due to the fact that throughout the evolution of this ceremony, its underlying relational dynamic has remained the same. In the first version, the passive, unfeeling earth is made to inflict pain upon the youths who obviously feel it. In the second, the youths are led to exhibit hostile feelings towards and actively inflict pain upon the patently unfeeling ground. In both cases, the youths' intimate experience of the territory they perambulate takes the form of a highly irregular type of enactment in which the emotions and intentions appropriate to the infliction of pain are contrived to be at once present (on one side of the relationship) and absent (on the other). In the first case, the territory is made to inflict pain upon the youths without actually inflicting pain; in the second, the youths are made to inflict pain upon the territory without actually inflicting pain upon it.

From this point of view, the nature of the experience undergone by the youths in perambulation remains conceptually unclear. It is not fully accountable in terms of ordinary behaviour. At the same time, however, the undeniable affective features of this performance (those entailing the infliction of pain), and what may be called its pragmatic consequences (the subsequent ability to give true testimony), attest to the fact that more than simple playacting is involved. Its meaningfulness therefore requires the supposition of some other, extraordinary source of intelligence, concretised in the ritual enactment itself. The degree of selfreference involved here becomes clearer when it is pointed out that the link between the celebrating community (representatives) and the territory in question, is itself derived, in part, from previous processionings, namely those undergone by the community representative and other community members. The ritual relationship enacted between processioning individuals and the territory they perambulate is thus embedded in prior actualisations of itself.

As the variability of the ethnographic material covering several hundred years makes clear, what is strictly defined here are not so much particular items of behaviour, but a specific interactive pattern into which they are integrated. Perambulation derives its unity not from the recurrence of a stereotypic sequence of actions -- in other words, a script --, but from the stability of its underlying relational dynamic.

With these observations in mind, let us now turn to a slightly more complex case of the ritual articulation of pain and place, as provided in the gisaro ceremony of the Kaluli people of the Southern Highlands area of Papua New Guinea.

\section{Bringing Other People's Places to Mind}

Gisaro is performed at a 'formal social occasion' (Schieffelin 1976: 21) by men of a distant, visiting longhouse community for the members of an inviting longhouse. It takes place within the hosts' longhouse, whose central aisle has been illuminated by torches held by a number of young men. The spectators are seated by family in the shadows on sleeping platforms on either side of this central space. The visitors enter in a group, parting to reveal several sumptuously decorated dancers. Throughout the night, the dancers, one by one, with grave, down-cast faces and withdrawn manner, dance in place or move slowly up and down the hall, singly softly to the accompaniment of choruses seated at each end. Dressed as birds, animals closely associated with the spirits of the dead, the dancers sing haunting songs organised around the place names of the host's clan lands: current and past garden clearings and longhouse locations, sago places, waterfall pools, etc. These references to the surrounding landscape are combined with unspecified images of abandonment, loss and loneliness: 'A kalo bird at Dubia Ridge is calling juu...juu' (Schieffelin 1976: 179), 'the Wa waterfall goes gulu [onomatopoeia] where someone has begun to beat sago' (Feld 1982: 
138). The singing 'projects members of the audience back along their lives, through images of places they have known in the past' (Schieffelin 1976: 197), leading them to 'fill in' the song's blanks with memories of recently deceased persons associated with the locations mentioned. The listeners are deeply moved. Indeed, the aim of these songs is to make them weep. The following reaction is typical:

'The senior man, who was sitting with the crowd at the sidelines, brooding and withdrawn, suddenly became overcome with grief and burst into loud wails of anguish. Enraged, he jumped up, grabbed a torch from a bystander and jammed the burning end into the dancer's bare shoulder. [...] The dancer was momentarily lost in a frightening pandemonium of shadowy figures, torches and showers of sparks. Showing no signs of pain, he moved slowly across the dancing space; the chorus burst into song. The senior man broke away from the crowd and ran out the back door of the house to wail on the veranda (Schieffelin 1976: 24).

This scene is repeated over and over until dawn, at which time the visitors abruptly bring their performance to an end. 'The dancers, whose shoulders were quite badly burned, then paid compensation to those they had made weep, and all the visitors trouped out of the house to go home. Since many people wept, the ceremony was felt to have been a good one. Some of the visitors left wailing out of sympathy with their grief-stricken relatives among the hosts' (Schieffelin 1976: 24). At a later occasion, the visitors will receive their hosts as the 'singing detectives' (Munn 1995: 86) of their own past.

The topographical rememberings occasioned by gisaro songs, like those brought about by perambulations, consist in the establishment of a painful, added familiarity with certain previously known places, and the embedding of this renewed connection within a particular network of interpersonal relationships. In the gisaro ceremony, however, the situation is a bit more complicated. Unlike the perambulating youths, gisaro hosts are not placed into contact with their homeland places and deceased kin directly, but through the intermediary of place-names sung by persons whose dead and whose homelands are not their own.

This somewhat equivocal character of the relational framework underlying gisaro performances has been discussed by Munn in a recent analysis of gisaro songs as 'memory worlds' (1995: 87), that is, models capable of triggering biographical memories. Gisaro remembering, she argues, is a 'complex constitutive act', which 'occurs only in the recognition of separation from or loss of co-presence with close others (aspects of the rememberer's self), realised in contrast to the current co-presence of external, distant others (the "not-self"), who yet sing one's place names. [...] The condensation of these contradictions within the rememberer's body is grief and anger -- the interiorized, bodily "subjective correlative" (to twist T.S. Eliot's phrase) of the contradictory symbolic field' (1995: 89). For her, the primary focus of this field is the singing of the songs, and in particular, the recitation of that particularly intimate, body-imbued aspect of Kaluli self which are place-names. Without denying the relevance of this analysis, but looking to shift the emphasis from the discursive to the interactive realm, I would like to concentrate on the other central feature of this ritual: the burning of the dancers.

For Schieffelin, the listeners, in plunging the torches against the dancer's shoulders, 'return pain for anguish, transform their sorrow by releasing it in anger, and turn their vulnerability into strength and positive action.' (1969: 206). For Munn, they 'transpose their interior mental pain onto the bodily surface of the outside singer' (1995: 86). Specifically, in an initial movement, 'the listener converts the song into memory -- as if reappropriating the alienated name by converting it back into the self-related meanings for which it is a currency. [Then], moving towards completion of this self-constructive process by defining him or 
herself in opposition to the outsider, the rememberer converts interiority (i.e. "myself", my mental pain of memory in which past co-presences come to mind) into the exterior pain (burning) of the currently co-present other' (Munn 1995: 91). Expanding upon this last remark, but laying stress less upon the memories gisaro brings into play than upon the relationships its enactment implies, I would argue that the hosts' castigation of the visitors may be understood in two complementary ways.

On the one hand, by inflicting pain on the visitors' bodies, the listeners introduce a clear existential separation between the singers and themselves. Indeed, prior to the hosts' violent intervention, this distinction becomes somewhat blurred, giving rise to an invasive confusion:

'[In gisaro], instead of the aggravation of fighting hostility, there is the intensification of excruciating intimacy. [...] The grief evoked by the songs becomes in this way something of an intrusion. [...] "When the dancer sings about Alimsok", one informant said, "I am reminded of my dead wife, Yano, who planted pandanus and breadfruit there with me. [...] I feel, "Why do you sing about my gardens? Why do you say I am alone? What do you mean? Kadaaa!' (he plunges the torch)" Another informant said, "Who is he to speak of my sorrow? He doesn't belong here!"' (Schieffelin 1969: 190).

The underlying uncertainty in perambulation concerns the nature of the painful experiences the participants are made to undergo. Here it concerns the identity of those who undergo them: who does the person-and-place connection being sung about belong to, the singer whose absorbing performance creates it or the listener who, in recognising it, makes it his/her own? From the anguished listeners' point of view, the burning of the outside singers brutally resolves this issue by banishing the possibility of such interpersonal confusion. By inflicting bodily pain themselves, the hosts claim the painful memories and relationships forced upon them as their own.

At the same time, the hosts' application of burning torches to the visitors' shoulders, is the interactive complement of the latters' singing. The gisaro hosts, waiting expectantly in the darkened sidelines, startled 'as though dealt an invisible blow' (Schieffelin 1969: 190) upon hearing their land names sung, overcome by grief and anger as their deceased loved ones are brought to mind, are to a large degree directed by their personal feelings. This contrasts markedly with the visitors who appear as the very embodiment of conventionization. Decorated in stunning but anonymous regalia, 'their individuality [is] submerged, [...] their image [...] elevated to an abstraction' (Schieffelin 1996: 177). In keeping with the contrast between these two parties, whereas the visitors inflict interior, psychological pain upon their hosts, the latter inflict exterior, physical pain upon the dancers. Indeed, unlike the listeners' hurt which leaves no marks upon the skin, the dancers' suffering is restricted to the surface of their bodies: the visitors' unchanging attitude of 'unresponsive obliviousness, which is unaffected by anything the audience might do' (Schieffelin 1969: 189), dramatically attests that their inner selves are not touched. Clearly, a 'contradictory symbolic field' obtains not only in the visitor's singing but here as well. Whereas gisaro singing recalls the first version of Perambulation in which youths 'take pains' in traversing an unfeeling territory, the gisaro burning recalls the second version of Perambulation in which the youths flail at the insensate land: in both the singing and in the burning of gisaro, the hosts are made to suffer their emotions while the visitors, who in one case inflict pain and in the other endure it, remain apparently unaffected.

This progressive building up of the ritual relationship between gisaro performers and members of the audience is closely meshed with an actualisation of the latters' personal ties with their own deceased loved ones. Consider for example the 'returns' occasioned by the two 
instances of inflicted pain which are gisaro singing and gisaro burning: tears and gifts respectively. On the one hand, the listeners' 'reappropriation of [their] alienated [place-] names' (Munn 1995: 91) during the visitors' singing is only truly completed with their letting go in uncontrolled wailing. On the other hand and in the same way, the 'self-constructive process' (ibid) initiated by the burning of the dancers is only fully consummated when the later offer compensation -- typically ornamental objects such as shell necklaces, chest bands, body paints, mirrors, clothes, etc. (Schieffelin 1969: 194, 208-209) -- to those whom they move to tears: 'without [compensation] one suffers in lonely, angry humiliation, deprived of acknowledgement or release from the pain of his situation' (ibid. 206). While the listeners' outward weeping demonstrates the aptness or emotional validity of the dancer's song, reciprocally, the decorative items offered by the visitors constitute a recognition that the listener's emotional outbursts are legitimately founded and not just empty histrionics. ${ }^{6}$ And, more generally, whereas the listeners' unbridled vehemence and passionate laments give feeling to the visitors' formulaic songs, the visitors' songs and the compensations they offer give culturally recognised form to the listeners' individual feelings.

In this way, the dancers' singing and the listeners' burning, the hosts' crying and the visitors' gift-giving, combine to produce two quite different things. Not only does the gisaro ceremony bring forth biographical memories, it also gives rise to what may be thought of as a shared, social remembering. Munn points out that certain discursive features of gisaro songs (absence of proper names, deictic and relative usages) emphasise relations between persons rather than particularised identity (1995: 92). Consequently, unlike what happens in spirit seances for example (Schieffelin 1985), it is not the dead relatives themselves who are brought into the longhouse 'but the distanced mode of their co-presence -- i.e. absence or loss itself' (Munn 1995: 93). I would add that, in similar, complementary fashion, certain performative features of gisaro action (the hosts' ostentatious lack of control, the dancers' consistent impassivity) place emphasis upon undirected intentionality rather than upon particular beliefs or desires. As a result, it is thus not so much the foreign singers' individualities that are brought to the fore, as it is the intimate mode of their otherness, i.e. presence or relationship itself. This, then, would seem to be the conventional affective experience brought about by gisaro performances, embodied in the poignant songs the dancers sing and in the vicious burnings they stoically endure: a melding of undeniable presence and irretrievable loss.

As I suggested in connection with perambulations, the particular reactualization of personal ties with place the gisaro ritual effects, the distinctive way in which it informs the individual experiences and memories it makes use of, in short, its 'work', consists in their recontexualisation. These experiences and memories, and the connections with particular places and persons they imply, are integrated into the relational network presupposed by the ritual performance itself. This network includes of course links with other participating individuals, as well as with their respective deceased kin and clan lands. But that is not all. Thus, an essential component of gisaro, in the absence of which no one will weep for a dancer's songs, is a carved stick he carries enclosing a piece of rock crystal received from the spirit of a dead relative; as Schieffelin observes: 'The invisible dead themselves provide their visible sons [the dancers] with the means [...] of continuing the performance' (1969: 222).

\footnotetext{
${ }^{6}$ It is mainly for this reason and not for their intrinsic value that the evaluation of these objects 'animates the discussion in the longhouse after every ceremony after the dancers have left. Those who feel slighted in compensation go off to ask for more. If no compensation is forthcoming, as sometimes happens, bad feeling arises, which is carried over for expression and resolution into the context of the next ceremony. This was the motivation for almost every comment I heard people make about intending to burn someone at a forthcoming ceremony' (1969: 206).
} 
Moreover, the fact that gisaro songs are used on other occasions such as spirit seances (Schieffelin 1969: 213), and that uncompensated (or overcompensated) griefs are carried over from one gisaro to the next within the framework of reciprocal performances between longhouses (cf. note 6 supra), means that this network is both considerably wider and more dynamic than might at first appear (cf. also Munn 1995: 86). Indeed, as in the case of perambulation, the painfully activated connections between people and places which emerge from gisaro celebrations are to a certain extent grounded in this ritual's recursive reference to itself. In this way, gisaro institutes an extra-ordinary yet indisputable context for everyday discourse and action in which individuals of neighbouring longhouses, their cherished dead, their clan lands and land names, their performances, songs, costumes, etc., may be deemed to be necessarily interconnected.

A further, still more complex example of the ritual articulation of pain and place will allow us to consider the construction of one such overarching, contextual network in greater detail.

\section{Landscaping a Man}

One of the most systematically developed cases of a ritually mediated association of pain and place is to be found among the Aboriginal populations of the Central Desert region of Australia. ${ }^{7}$

Aranda country is characterised by a series of criss-crossing tracks tracing the perambulations of wondrous entities whose hybrid nature associates them with particular animal or plant species. These entities' travels across, underneath and over the land, their meetings with each other, their fights, amorous adventures, ritual performances, etc., have resulted in the landscape's observable features. The areas through which these beings are said to have travelled are animated by embryonic, spore-like elements, called 'spirit children' in the literature, relating to the animal or plant life forms associated with the entities concerned. At the end of their wanderings, these beings did not just disappear but entered into the earth, becoming, as it were, the various records of themselves and their activities they left behind. These remnants or relics, generically called tjuringa, represent the chief sacra of the Aranda. In so far as the landscape is concerned, two main kinds may be distinguished: (1) certain immobile features of the environment itself (rock holes, outcroppings, boulders, caves, etc.) which constitute totemic sites, and (2) oblong slabs of stone (or wood) kept in special storehouses hidden near totemic sites and engraved with designs tracing (a section of) the itinerary of the relevant entity's wanderings. The spirit-children dwelling at a given totemic site give rise to the young of the species associated with this site, whereas those associated with the tjuringa slabs stored in proximity to this a site give rise to human beings who have this species as their totem. Animal conception, for example, is held to occur when a spiritchild enters the womb of a pregnant female living in or passing through the area. In the case of humans, such an incarnation is said to 'leave behind' a tjuringa slab. Thus, each individual has his or her own personal tjuringa engraved with a unique pattern. Only initiated men are allowed to see and handle these objects; only they are allowed to know the secret names, stories and songs associated with the travels of the entities from which these objects derive, and which allow for an interpretation of their designs.

This network of ties linking people, places, objects, designs, stories, songs, names, various invisible agents, etc., into what Aboriginal people call 'the Dreaming' (or 'the Law'),

\footnotetext{
${ }^{7}$ The following thumb-nail sketch relies principally on Moisseeff's recent (1995) synthetic interpretation of Aranda ritual and social organisation, based on Spencer and Gillen's (1927) and Strehlow's $(1947,1971)$ turnof-the-century observations (see also Morton 1985 and Testart 1992 for alternative accounts).
} 
is in large part upheld by an elaborate ritual system. Persons connected with the same totemic site regularly perform increase rites there in order to promote the multiplication of their totemic species. Also, a lengthy initiation process entailing the manipulation of personal tjuringa produces initiated men capable of directing such increase rites, and at the same time, though the ceremonies attendant upon its execution, promotes the incarnation of human spirit-children. All these ceremonies invariably involve the intimate handling of Tjuringa, the construction of intricate costumes in which the actors disappear beneath a massed combination of coloured ochres, feathers, twigs, hair-strings, thick patterns of vegetable down stuck on with blood, etc., built around tjuringa (usually attached to the dancer's head), the execution of zoomorphic dances portraying totemic entities, and the chanted recitation of their journeys.

The initiation cycle by which individuals are made capable of performing such rites, that is, of incarnating the Dreaming beings and their travels, is in many respects the keystone of Aranda ceremonial. Covering a period of about twenty years, it entails a variety of painful episodes: being tossed in the air ('the boy [...] is hit whilst in the air on the breast and back, sometimes until he begins to bleed from nose and mouth' [Strehlow 1971: 396]), circumcision, having one's penis 'opened' through subincision, having one's head 'opened' (to promote hair growth) by deep biting on the scalp and chin, being repeatedly 'smoked' and 'dried out' over fires, having one's forehead dashed against a shield 'till it begins to swell' (Strehlow 1974: 413), etc. I wish to concentrate briefly on one such episode, which marks the climax of the initiation process: the initiate's first encounter with his personal tjuringa, 'one of the most important occasions in his life' (Strehlow 1971: 414).

According to Spencer and Gillen (1927: 113-116), the (Southern and Central Aranda) initiate is obliquely told that he will be shown his personal tjuringa and is instructed to go hunting. Upon his return, he is summoned to a place near the storehouse where a dozen or so men have made a ground-drawing of the man's totem which they have covered over with branches. As he draws near, he is grabbed by his whiskers and pulled up close to where the totemic ground-drawing is hidden. The drawing is uncovered and he is made to sit down upon it; he is told not to look at it, to make no noise during what follows and not to resist (under penalty of death). The gathered men look intensely at each other and take hold of the little fingers of the initiate's hands. While his hands are tightly held, an elder man presses an opossum tooth (embedded in the jaw which is used as a handle) under each thumb nail and tears it off. The men then lay the initiate on his back on top of the ground drawing and, while in this position, using an opossum tooth, they carve the design of his personal tjuringa upon his forehead. The blood from the scratches is rubbed over his forehead by the older man. He is then shown the ground drawing and told to rub it with his forehead. The old men tell him his secret, tjuringa name assigned to him from birth. He is made to sit down beside the ground painting which is explained to him. Finally, his personal tjuringa, whose design is also explained, is placed into his hands. 'I want to tell you', the old man informs him, 'this is your tjuringa; you came out of the tjuringa; your tjuringa name is so-and-so'. He is told that henceforth he must use opossum teeth to engrave tjuringa with the design similar to that on his own personal tjuringa. His tjuringa then is returned to the storehouse and the ritual is over.

Strehlow describes a similar scene (without the forehead engraving however) among the Northern Aranda, adding that the verses the men sing on this occasion concern Dreaming beings who fashion tjuringa 'that could be placed upon their heads' (Strehlow 1971: 414); wishing to decorate themselves in order to perform a ceremony, they tear the nails off their thumbs and first fingers and use the spurting blood to glue on the ceremonial down. According to another, Western Aranda tradition, the relevant verses, also chanted by old men 
'when [...] using the possum jaw bone with its sharp front tooth in order to engrave newlyfashioned tjuringa slabs' (Strehlow 1971: 415), tell of a young Opossum being who lacerates the hardened ground with his teeth. Finally, Strehlow mentions that the old men inform the initiate that his thumb and finger nails are being torn off 'so that he can inscribe tjuringa' (Strehlow 1971: 415), or in order to make his hands more pliable when carving tjuringa designs (Strehlow 1947: 113). ${ }^{8}$

This sequence is closely entwined with other, prior or subsequent ritual episodes such that it is difficult to do more than indicate in an approximate fashion certain of the performance's overall orientations. As in the other rituals we have examined, the infliction of pain is here of an evidently out of the ordinary nature. Specifically, the initiate's experience of suffering has a paradoxical quality typical of so many initiation ordeals (Houseman 1986, 1993). Thus, the Aranda initiate is enabled to fashion tjuringa by being himself fashioned by the very instrument he must henceforth use: he is either rendered (temporarily) incapable of working an object with his hands and/or is himself engraved with the pattern he must thereafter inscribe. What is at stake here is not the imposition of an exterior sign (the initiate's nails grow back and the scratches on his forehead do not leave scars), but the fulfilment of a transformative experience. In the case of perambulation, as we have seen, upended youths have their heads 'bumped' against the boundary stones of their estate. Here, the initiates have their heads imprinted with a map of their country. In both cases, a novel familiarity with their homelands is being painfully impressed upon them.

The various identifications acted out in this performance provide an indication as to the nature of the ritual relationship in which initiate's link with his country is embedded. The foremost of these is the identification between the initiate and his personal tjuringa (Moisseeff 1995: 147). As Moisseeff has shown, this episode represents the culmination of a long process, concentrated upon the head of the novice, whereby the initiate is transformed into an analogue of his 'better half' encountered here for the first time: 'the initiate/tjuringa confrontation is presented as the reunification of an entity that was divided into two at the moment of incarnation' (ibid 145). In Moisseeff's view, the initiation cycle follows from this initial separation of the individual's incarnated spirit-child and its associated tjuringa. It corresponds to the difficult passage from the 'carnal' unity of the uninitiated boy with his mother to the 'spiritual' unity of the initiated man with the Dreaming relic from which he sprang, passage entailing a spatial displacement from the tjuringa storehouse to the (woman's) camp and back again (ibid 144-151). In this way, the link between the initiate and his personal tjuringa has a dynamic dimension as well. The initiate, whose spirit-child derives from a tjuringa the singularity of which is determined by the pattern it bears, acquires (in his head and in his hands) the means of manufacturing tjuringa with an identical design.

\footnotetext{
${ }^{8}$ Strehlow's account (1947: 113), as told by one of his informants, makes clear the extreme pain this operation entails:

'The old men seized my hand. They all struck up the chant-verse:

With fierce eyes, with glowing eyes, they seize the thumb ;

With fierce eyes, with glowing eyes, they rip off the nail.

An old man produced a sharp kangaroo bone [...]. He stabbed my thumb with it, pushed the bone deeply underneath the nail. He drew the point out ; the rest kept up the chant. He thrust it under the nail in a different place. He gradually loosened the thumb nail. It was slippery with blood. I almost shrieked with pain ; the torment was unbearable. I have not forgotten it : the pain was not slight ; it was exceedingly great. When the nail had been loosened, he took a sharp opossum tooth, forced it into the living flesh through the base of the thumb-nail, and tore the nail off from behind. Blood spurted over his hand. The men chanted :
}

They rip off the nail, they tear off the nail ;

Blood flows like a river, rushes along like a river.

Then they seized my left hand and removed the thumb-nail in like manner.' 
They are thus bound together into a relationship of reciprocal engendering -- each proceeding from the other -- in which the fully initiated man may be held to carry within himself the conditions of his own emergence.

This complex tie which initiation establishes between the novice and his personal tjuringa is further augmented by similarly recursive relationships linking one and the other with the landscape and the beings from whose wanderings it is said to have arisen. The tjuringa is a concrete remnant of a particular totemic being, etched with the itinerary of the entity from which it derives. 'It is a parcel of landscape upon which is inscribed -- as traces -the movement through the landscape of which it represents the trace' (Moisseeff 1994: 23-4). At the same time, the initiate, likened to the hardened earth scored by opossum teeth, his head incised in the fashion of the ground-drawing upon which he is made to sit and to which his head, rendered homologous, is joined, is identified with the landscape as well. Moreover, as an initiated man, capable of naming himself, of creating his own tjuringa and grounddrawings, of reciting the itineraries linking successive totemic sites, of travelling these routes himself in order to perform increase rites and to partake in major ceremonial events (such as initiations), the initiate demonstrates the self-referential qualities of the totemic beings from which he springs. ${ }^{9}$ Coupled with a 'mobile landscape' (Moisseeff 1995: 22), that is, with the stone relic of a Dreaming being of which he is the carnal manifestation, the fully initiated individual becomes an embodiment at once of his country and of the invisible entities whose powers he is thought to acquire (Strehlow 1997: 416-417).

As in the cases previously examined, the special relationship painfully forged here between the initiate and his homelands, specifically through the intermediary of his encounter with the place-object which is his tjuringa, is distinguished by an essential conceptual indeterminacy, such that the intelligibility of this relationship requires a reference to the ritual action itself. This indeterminacy consists above all in a systematic blurring of ontological distinctions in which, contrary to Korzibsky's famous dictum, map and territory, name and named, creator and created, etc., are held to be one and the same.

Because the various identifications acted out in Aranda initiation incorporate such a considerable degree of recursive reference, the ritual relationship these identifications define, and the higher-order network this ritual relationship implies, have the self-scaling quality characteristic of so many fractal objects. The persons, actions, objects and discursive elements this network involves are made to appear as so many self-similar aspects of a single, instantiated totality: the Dreaming. Fully initiated men are constituted as the repositories of this all-encompassing entirety, as microcosmic beings who, potentially, contain everything, even their environment, within themselves. It is thus through the coordinate actions of such autonomous individuals -- in Moisseeff's (1995) terms, through the dynamic association of such singularities -- notably when they participate together with their tjuringa in large-scale ceremonies, tracing out totemic tracks and impersonating totemic beings, that the Dreaming is recreated and the landscape itself is brought into fullness. This comprehensive context in which complex linkages between persons and between persons and places (and objects and actions and words and melodies, etc.) may be appreciated as part of an ordered whole, derives in an essential manner from the ritual process of initiation. It is experientially anchored in the corporeal experiences this ritual process entails, not the least of which is the infliction of pain.

\footnotetext{
${ }^{9}$ The modification of totemic Dreaming tracts in accordance with changing social conditions and relations between groups, like the fabrication of tjuringa, is presented as a remembering or restitution of the original itineraries or objects which have been lost or forgotten. Dreams play a major role in the introduction of such structural adjustments (cf. for example Moisseeff 1995: 247-254).
} 


\section{Conclusion}

The preceding cases illustrate the ritual association of pain and place at successively higher levels of organisation in terms of both the participants involved and the territories concerned: the delimitation of a parish or manor, two longhouse communities and their respective clan lands, the surrounding landscape of an Aboriginal society. These cases are also increasingly complex in that they make use of a progressively greater number of mediating elements: perambulations concern places (or place-markers) alone, gisaro ceremonies deal with both places and place-names, the Aranda initiate's reunion with his tjuringa incorporates places, place-names and place-objects.

These rituals do not create links between persons and place: English parishioners, Kaluli farmers and Aboriginal hunter-gatherers, all come to these events with a prior knowledge of the territory they live on. Rather, they recontexualize pre-existing links with land. The infliction of pain plays a central role in this ceremonial recontexualisation. It both imbues these pre-existing links with the immediacy of new, incontestable bodily experiences, and encapsulates these experiences within a wider network of ties, namely, those presupposed by the pain-inducing relationship acted out in the rituals themselves. In this way, the participants' relations with their lived-in environment are renewed and radically transformed. Contingent, individual-specific connections with places more or less welldefined in terms of everyday use and familiarity, acquire additional if somewhat indeterminate meaning as necessary, constitutive aspects of the persons themselves. Particular locations are instituted as the depositories of people's social personhood, thereby furnishing the grounds for an at once more intimate and more conventional fit between community members and their physical surroundings. To almost quote Dorothy's heartening incantation in the Wizard of $\mathrm{Oz}$, these rituals proceed from and further substantiate the very sensible contention that there's no place like (one's) home(lands).

In more anthropologically familiar terms, these rituals establish a 'relationship' between the people and the places concerned. More rigorously speaking, they give rise to representations in which peoples' connections with portions of the unthinking, unfeeling environment are attributed with features typical of interpersonal relationship: interaction, intentionality, affect, accountability. The places in question cease being mere objects to become virtual subjects themselves: parish boundaries that aggress or are aggressed by parish children, clan lands that haunt their inhabitants, Dreaming sites that engender their owners. Such presumptions of relationship between persons and places -- and perhaps more generally, between persons and inanimate objects, invisible entities, liturgical formulae, and so forth -- would seem to derive, at least in part, from the conjunction of two things: (1) an undeniable bodily experience - such as pain -- attributable to an encounter with the places in question, and (2) a causal embedding of this experience in a network of interpersonal ties. A further consideration pertains to the conditions in which the association of (1) and (2) is realised. These conditions determine the extent to which the representations deriving from this association will either remain short-lived and particularistic or on the contrary persist as easily acknowledgeable, widespread phenomena. Ritual enactments, I have suggested, typically entail a conventional condensation of nominally contrary modes of relationship, for example, a simultaneous acting out of the infliction and the non-infliction of pain. In this respect, they can not be adequately accounted for or challenged in terms of ordinary intentionalities or patterns of behaviour. At the same time, to the extent that such enactments are nevertheless deemed meaningful, their intelligibility entails a reference to past, present or future instances of the ritual performance itself. The relationships acted out in ritual events, and the integrative contexts these relationships imply, are thus upheld by circuits of recursive 
reference which confer a measure of indisputable authority upon them. It is easy to imagine how (representations of) relationships between people and places built up within such a framework can become prevalent and acquire stability over time.

Imposed suffering is of course not the only means through which ritual relationships with places can be built up. The exaction of other distinctive affective conditions - sexual or aesthetic ecstasy, certain altered states of consciousness such as trance or intoxication -might, I suppose, work as well, affording bodily experiences of the places encountered and causally embedding these experiences in particular interactive situations. However, pain seems particularly well-suited in this respect. To begin with, it is markedly unpleasant, such that what one might call the ludic hypothesis of ritual action - 'it's all but a game' - is cast into doubt. The participants find themselves incapable of not attributing some measure of 'serious' intelligibility to painful enactments whose meaning remains nonetheless unclear to them. Moreover, as has already been mentioned, the intentional 'depth' of patently imposed suffering provides this particular modality of intimate experience, perhaps more than any other, with a high potential for shared meaning and direction (cf. Houseman 1998; also Scary's [1984: 15] discussion of 'language of agency' and Boltanski's [1993] analysis of spectacles of suffering). It is of course impossible to feel another person's pain and in this sense a direct sharing of suffering is out of the question. However, because we are all familiar with the intentional and affective underpinnings of inflicting pain and/or having pain inflicted upon oneself, ritual actions incorporating such situations are easily invested with one's own personal feelings and imagination. In short, inflicted pain provides a particularly memorable focus for a shared commitment to the ritual relationships the participants enact.

To conclude, I wish to touch very briefly upon the question implicitly raised here regarding the type of memories such painful, disorientating ritual experiences entail. We have seen how the contradictory elements they incorporate, together with their pain-inducing character, render these experiences resistant to a definite conceptualisation by those who undergo them. At the same time, however, there is little evidence of psychological trauma in the accepted technical sense of the term. Former processioners, gisaro singers and hosts, Aranda initiates, all appear to be able to recall these difficult episodes at will, to talk about them afterwards and to draw inferences from them. In contrast, traumatic events typically entail a much more complete blockage of conceptual processing, as attested by amnesia and/or intrusive memories (such as flashbacks) in which past and present are indistinguishable. What type of memories, then, do such pseudo- or semi-traumatic events occasion? In 'epidemiological' terms (Sperber 1985, 1996; cf. also Whitehouse 1996a), what are the participants' mental representations which at once result from these public enactments and which provide the causal grounds for their subsequent reiteration?

Whitehouse (1996b) has recently argued that the highly emotional and cognitively shocking events found in 'rites of terror' (such as certain initiation ceremonies), trigger what are called 'flashbulb memories' (Brown and Kulik 1982): an instantaneous encoding of the perceptible environment which is impressed as a whole in the mind. It is interesting in this light to contrast such ritual situations with the phenomena of implicit memory (Schacter 1987). Loosely speaking, implicit memory refers to the acquisition of knowledge in the absence of explicit recall: I cook certain dishes the way my mother did but do not remember ever having learned to do so; without realising it, I almost exactly reproduce a close colleague's ideas. There is no recollection of the actual learning situation (episodic memory), and yet the items in question are part of my everyday general knowledge of the world (semantic memory; for the episodic/semantic distinction, cf. Tulving 1972). In rituals such as those analysed above, the inverse phenomena would seem to occur. Explicit recall of a learning situation exists in the absence of knowledge acquisition. The perambulating child, 
the gisaro participants, the Aranda novice, all retain a vivid memory of the particular experiences they undergo (episodic memory); however, little if any additional knowledge (semantic memory) is actually acquired in these experiences. Whereas in implicit memories, particular items of semantic knowledge are brought to the fore, in what may be called 'contextual memories' such as those occasioned by painful, cognitively shocking ritual events, it is the learning situation itself, that is, the distinctive interactive pattern underlying these episodes, which is highlighted instead. In this perspective, it may be most fruitful to envisage such enigmatic ritual experiences as essentially priming phenomena. They activate the participants' aptitude to interpret subsequent (and prior) events and knowledge relating to these rituals -- deriving for example from discussions or from occupying different roles in other performances of the same rites -- in terms of the particular systems of relationship acted out in them.

\section{REFERENCES}

Boltanski, L. 1993. La souffrance à distance. Paris: Editions Métailié.

Brand, J. 1870. Observations of popular antiquities. Newcastle-upon-Tyre: T. Saint [1777].

Brockie, W. 1974. Legends and superstitions of the county of Durham. Wakefield: EP Publishing [1886].

Brown, R. and J. Kullik. 1982. Flashbulb memory. In Memory observed: remembering in natural contexts. (ed.) U. Neisser. San Francisco: W.H. Freeman.

Burne, C.S. 1974. Shropshire folk-lore: a sheaf of gleanings. Wakefield: EP Publishing [1883].

Bushaway, B. 1982. By rite: custom, ceremony and community in England, 1700-1880. London: Junction Books.

Christian, R. 1966. Old English customs. Newton Abbot: David and Charles.

Cross, F.L. and E.A. Livingston 1974. The oxford dictionary of the Christian church. 2nd edition. London: Oxford University Press.

Detienne, M. 1990. Tracés de fondation. Peeters: Louvain.

Drake-Carnell, F.J. 1938. Old English customs and ceremonies. London: B.T. Batsford Ltd.

Feld, S. 1982. Sound and sentiment. birds, weeping, poetics and song in kaluli expression. Philadelphia: University of Pennsylvania Press.

Gussow, A. 1971. A sense of place. San Francisco:

Hackwood, F.W. 1974. Staffordshire customs, superstitions and folklore. Wakefield: EP Publishing [1924].

Hazlitt, W.C. (ed.) 1905. Faiths and folklore: a dictionary. London: Reeves and Turner.

Héritier, F. 1984. Stérilité, aridité, sécheresse. Quelques invariants de la pensée symbolique. In Le sens du mal. M. Augé and C. Herzlich (eds.).Paris: Editions des Archives contemporaines.

Hirsch, E. and M. O'Hanlon (eds.) 1995. The anthropology of landscape : perspectives on place and space. Oxford : Claredon Press.

Hole, Ch. 1975. English Traditional Customs. London: B.T. Batsford Ltd.

Houseman, M. 1986. Le mal pour le mâle : un bien initiatique. In Le Mal et la Douleur. J. Hainard and R. Kaehr (eds.). Neuchâtel: Musée d'ethnographie.

1993. The interactive basis of ritual effectiveness in a male initiation rite. In Cognitive aspects of religious behaviour. (ed.) P. Boyer. Cambridge: Cambridge University Press.

------ 1998. Quelques configurations relationelles de la douleur. In De la violence II. (ed.) F. Héritier. Paris: Editions Odile Jacob.

Houseman, M. and C. Severi 1994. Le naven ou le donner à voir : vers une théorie de l'action rituelle. Paris: Editions MSH / CNRS.

Hull, E. 1928. Folklore of the British Isles. London: Methuen and Co. Ltd.

Humphrey, C. and J. Laidlaw 1994 The archetypal actions of ritual. A theory of ritual illustrated by the Jain rite of worship. Oxford: Clarendon Press.

Kapferer, B. 1991. A celebration of demons. Exorcism and the aesthetics of healing in Sri Lanka. Oxfornd and Washington D.C.: Berg Publishers and Smithsonian Institution Press.

Kightly, C. 1986. The customs and ceremonies of Britain. An encyclopedia of Living Traditions. London: Thames and Hudson. 
Leclercq, H. 1932. Rogations. In Dictionnaire d'archéologie chrétienne et de liturgie. (eds.) F. Cabrol and H. Leclercq. Paris : Letouzey et Ané.

Moisseeff, M. 1994. Les objets cultuels aborigènes, ou comment représenter l'irreprésentable. Genèses 17:8-32.

------ 1995. Un long chemin semé d'objets cultuels. Le cycle initiatique aranda. Paris: Editions de l'Ecole des Hautes Etudes en Sciences Sociales (Cahiers de l'Homme).

Morton, J. 1985. Sustaining desire. A Structuralist interpretation of myth and male cult in Central Australia. $\mathrm{PhD}$ Dissertation, Australian National University, Canberra.

Munn, N.D. 1995. An essay on the symbolic construction of memory in the Kaluli gisaro. Cosmos and Society in Oceania. In (eds.) D. de Copet and A. Iteanu. Oxford: Berg.

Parkin, D. 1992. Ritual as spatial direction and bodily division. In Understanding rituals. (ed.) D. de Coppet. London and New York: Routledge.

Porter, E. 1969. Cambridgeshire customs and folklore. London: Routledge and Kegan Paul.

Powers-Beck, J. 1995. Not only a pastour, but a lawyer also: George Herbert's vision of Stuart magistracy. Early Modern Literary Studies 1.2:1-25.

Scarry, E. 1985. The body in pain. The making and the unmaking of the world. Oxford: Oxford University Press.

Schieffelin, E.L. 1976. The sorrow of the lonely and the burning of the dancers. New York: Saint Martins Press.

1985. Performance and the cultural construction of reality. American Ethnologist 12:707-724.

Scott, Ch. 1995. Custom: the great guide of human life. From mallards to tortoises, Christina Scott marvels at the traditions of Oxford. Oxford tradition online

Schacter, D.L. 1987. Implicit memory: history and current status. Journal of Experimental Psychology: learning, memory and Cognition 13:501-518.

Schechner, R. and W. Appel (eds.) 1990. By means of performance. Intercultural studies of theatre and ritual. Cambridge: Cambridge University Press.

Severi, C. 1987. The invisible path: ritual representation of suffering in Cuna traditional thought. Res Anthropology and Aesthetics 14: 66-85.

Shuel, B. 1985. The national trust guide to traditional customs of Britain. Exeter: Webb and Bower.

Smith, J.Z. 1987. To take place. Toward a theory of ritual. Chicago: University of Chicago Press.

Strehlow, T.G.H. 1947.Aranda traditions. Melbourne : Melbourne University Press.

1971 Songs of central Australia. Sydney : Angus and Robertson.

Spencer, B. and F. Gillen 1927. The Arunta. London : MacMillan.

Sperber, D. 1985. Anthropology and psychology: Towards an epidemiology of representations. Man (N.S.) 20:73-89.

1996. La contagion des idées. Paris: Editions Odile Jacob

Tuan, Y.F. 1977. Space and place. The perspective of experience. Minneapolis: University of Minnesota Press.

Testart, A. 1992. De la nécessité dêtre initié. Rites d'Australie. Paris : Société d'ethnologie.

Tulving, E. 1972. Episodic and semantic memory. In Organization of Memory. (eds.) W. Donaldson and E. Tulving. New York: Academic Press.

Udal, J.S. 1922. Dorsetshire folklore. Saint Peter Port (Guernsey): Tocan Press.

Werbner, R. 1989. Ritual passage, sacred journey: the process and organisation of religious movement. Washinton D.C.: Smithsonian Institution Press.

Whitehouse, H. 1996a. Jungles and computers: neuronal group selection and the epidemiology of representations. Journal of the Royal Anthropological Institute (N.S.) 2: 99-116.

1996b. Rites of terror: emotion, metaphor and memory in Melanesian initiation cults. Journal of the Royal Anthropological Institute (N.S.) 2: 703-715.

Whitlock, R. 1976. The folklore of Wiltshire. London: B.T. Batsford Ltd. 